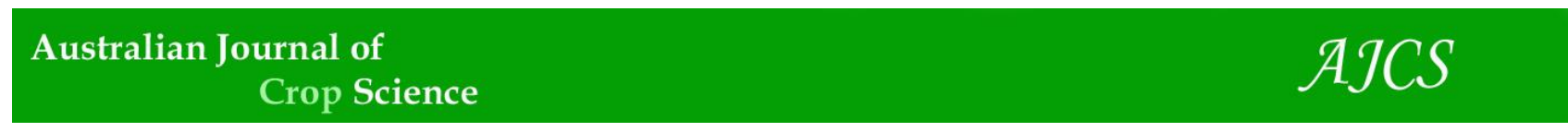

AJCS 12(05):763-769 (2018)

ISSN:1835-2707

doi: 10.21475/ajcs.18.12.05.PNE896

\title{
Phenotypic plasticity of upland rice lines cultivated in Minas Gerais State, Brazil
}

\author{
Hermínio B. Inácio ${ }^{1}$, Flávia B. S. Botelho ${ }^{1}$, Amanda M. de Moura ${ }^{1}$, Marcela P. Mendes-Resende ${ }^{2}$, Heloísa \\ O. dos Santos ${ }^{1}$, Adriano P. de Castro ${ }^{3}$, Moisés de S. Reis ${ }^{4}$, Fernanda O. Bustamante ${ }^{1 *}$
}

\author{
${ }^{1}$ Department of Agriculture, University Campus, Federal University of Lavras 37200-000, Lavras, MG, Brazil \\ ${ }^{2}$ Samambaia Campus, Federal University of Goiás 74690-900, Goiânia, GO, Brazil \\ ${ }^{3}$ Brazilian company of agricultural research-Rice and beans, Highway GO-462, Km 12, 75375-000, Santo Antônio de \\ Goiás, GO, Brazil \\ ${ }^{4}$ Agricultural Research Company of Minas Gerais, PO box 176, 37200-000, Lavras, MG, Brazil
}

\section{*Corresponding author: fobustamante@hotmail.com}

\section{Abstract}

The evaluation of breeding lines for prior recommendation in different environments is a step that requires a high level of investment. This evaluation is extremely important, especially when the objective of breeding is to select lines with high homeostasis, adaptability associated with high yield, and stability. Thus, this paper aimed to study the phenotypic plasticity of thirteen upland rice lines for grain yield in multiple environments of Minas Gerais State, Brazil. The experiments were installed in nine different environments corresponding to the combination of locations and agricultural years. Thirteen elite lines were used, originating from a partnership between UFLA (Federal University of Lavras), Epamig (Agricultural Research Company of Minas Gerais) and Embrapa (Brazilian Company of Agricultural Research) Rice and Beans. The experiments were conducted in a complete randomized block design with three replicates. Culture treatments used for conducting were the same as those recommended for culture. The evaluated character was grain yield $\left(\mathrm{kg}_{\mathrm{g}} \mathrm{ha}^{-1}\right)$. Adaptability and stability were estimated by the methods Wricke, Annicchiarico, and Lin and Binns. All experiments showed average productivities above average in the state of Minas Gerais. The methods by Anniccchiarico and Lin Binns were efficient for the lines identification with phenotypic plasticity, emphasis on the lines CMG 2097, CMG 1896 and CMG 2089, which obtained superior average performance with productivities higher than 5 t.ha $^{-1}$. Thus, these lines are promising for the Minas Gerais state recommendation, as well as in similar environments under low fertility natural soil, ferralsol (latosols), with tropical semi-humid and tropical altitude.

Keywords: Adaptability; breeding; grain productivity; Oryza sativa; stability.

Abbreviations: Embrapa_Brazilian Company of Agricultural Research; EPAMIG_Agricultural Research Company of Minas Gerais; Muquem_Muquem Experimental Farm; UFLA_Federal University of Lavras.

\section{Introduction}

Rice (Oryza sativa L.) is the third most produced and consumed cereal in the world, behind only from wheat and corn. It is part of the basic diet of approximately $50 \%$ of the world population and can be considered the most important cereal for human consumption (Walter et al., 2010). Until the 1970s, upland and flooded rice production was complementary to national supply, and competition between them was small because the products were divided between the two markets. Since the mid-70s, flooded rice has gained national preference and has gained higher quotes on market. However, in the early 1980s, the national average productivity of upland rice showed an increasing trend; despite reduction of cultivation area, production increased and grain quality significantly improved (Ferreira and Villar, 2003). Traditionally, upland rice cultivation in Brazil had been practiced without much technology, occurring only as an opening of new agricultural areas. Therefore, the crop presented low productivity and inferior quality to the Brazilian consumer standards, discouraging producers (Nascimento, 2008). Moreover, despite the availability of cultivars for the diverse edaphoclimatic conditions in Brazil, researches conducted in the 90s showed that the genetic base of upland rice is quite narrow, making it difficult to obtain superior cultivars. Rice cultivation is, among the annual crops planted in Brazil, one of the most sensitive to environmental adversities (poor soils, water deficiency, pest and disease attacks, etc.). These adversities result in low yields and unstable production over the years, leading to shortages, large price fluctuations and a drop in per capita consumption of this product, which represents one of the main Brazilian dishes (Morais et al., 2008). Around $13 \%$ of upland rice cultivation occurs without any type of irrigation and its productivity depends entirely on the water system of the growing region (Terra et al., 2013). Most of Brazil presents seasonal rainfall, often alternating with periods of water excess and deficiency, which can 
cause reduction in the production. The best alternative, in this case, is to obtain cultivars adapted to the growing regions, especially where no cultivation technology is used.

Among other reasons, this extreme sensitivity of the crop can be associated with the use of cultivars that are maladapted to the different production systems and the great variability of edaphoclimatic conditions in which rice is grown in Brazil. In this respect, the recommendation of cultivars based only on their average productivity in advanced yield trials may contribute to the indication of genotypes with specific adaptation. Thus, one of the successful strategies for recommending lines with broad phenotypic plasticity is their evaluation in a large number of different environments. The evaluation stage of genotypes for previous recommendation in different environments is a stage that requires a high level of investment. This evaluation is extremely important, especially when the breeding objective is to select lines with high homeostasis, adaptability, high production of genotypes associated with high yield, and stability (Balestre et al., 2010). Therefore, in a breeding program, it is extremely important to obtain lines that present a stable behavior against environmental oscillations (Santos, 2009).

There are several methods for studying and quantifying the genotype $x$ environment interaction, more specifically for rice, many methodologies have been used in breeding programs for the species (Morais et al., 2008; Borges et al., 2010; Regitano Neto et al., 2013). Among these methodologies, it is highlighted the proposal of Lin and Binns (1988) that compares the behavior of each lines with the highest average in each environment, so the lower the $\mathrm{Pi}$ estimate (deviation around maximum), the greater the productivity, adaptability and stability. Another methodology used is by Annicchiario (1992) method, in which stability is evaluated based on the confidence index estimation of a given genotype, that is, the risk estimate associated with the a given genotype adoption. It is also worth mentioning the ecovalence method (Wricke, 1965), wherein the sum of the squares of the environments $x$ genotypes interaction is decomposed, and the most stable genotype is the one with the lowest Wricke index, that is, it has the smallest contribution to the interaction.

Therefore, this paper aimed to study the stability and phenotypic plasticity of thirteen upland rice lines for grain yield using the methods of Lin and Binns, Annicchiarico and Wricke in nine environments of the Minas Gerais state, Brazil.

\section{Results and Discussion}

\section{Experimental accuracy}

The experimental accuracy was evaluated using the coefficient of variation (CV\%). All the experimental environments had CVs lower than $17 \%$ (Table 1). According to Pimentel-Gomes (2000), in field trials and coefficients of variation lower than $20 \%$, the experiments are classified as having good accuracy, where the estimates are obtained with reliability. Considering the joint analysis of variance, the experimental accuracy was good, with an estimate of $\mathrm{CV}(\%)$ lower than $16 \%$, and accuracy of $92.24 \%$.

\section{Grain productivity}

The average estimates of grain productivity ranged from $3,170.83 \mathrm{~kg} / \mathrm{ha}$ for Lambari's environment in the $15 / 16$ harvest to $7,631.74 \mathrm{~kg} / \mathrm{ha}$ at UFLA in the $13 / 14$ harvest (Table 1). It is worth mentioning that the results of the average productivities in all experiments are above the average of the Minas Gerais state (2.3 t/ha) (CONAB, 2016), a fact that initially demonstrates the success of the upland rice breeding program.

\section{Lines/genotypes, environments and lines/genotypes $x$ environments interaction}

The individual analyzes of variance verified that, in some environments, the lines had different behaviors. In five of the nine environments, the source of variation treatments was significant. In the remaining four environments, the lines had similar behavior, which means that they did not differ according to the F-test (Table 1). The existence of significant differences for the sources of variation lines/genotypes, environments and the interaction lines/genotypes $\mathrm{x}$ environments was detected by joint analysis of variance.

Similar results were also found by Molina (2007) for the rice cultivation, in which significant differences among genotypes were detected. The same occurred for the effect of environments and the interaction genotypes $x$ environments. This interaction indicates that the genotypes performance was not consistent at the evaluated locations and that the adaptability and stability analysis was adequate. This shows the different sensitivities of the genotypes to the different environments conditions, which, in the present study, are the conditions of soil, year and locality. Thus, it is important to identify lines with predictable behavior and that are responsive to environmental variations.

Studying the effect of two wheat sowing seasons in the Minas Gerais State, Cargnin et al. (2008) observed the interaction genotypes $x$ environments, concluding that, the genotypes had different responses regarding the environmental condition, possibly due to heat tolerance. The authors state that the grain yield was the most affected by environmental conditions, being the interaction, predominantly, a complex type, which restrains the selection and indication of the best genotypes.

Similar results were found for beans (Camargo Rocha et al., 2010). These results indicated that the evaluated genotypes genetically differed for potential of grain yield and that they presented different responses to the environments in which they were evaluated. Therefore, it was necessary to deploy the genotypes $x$ environments interaction, which was done through the use of stability and adaptability analyses. In conclusion, the edaphoclimatic factors are the ones that most influenced the adaptability and the stability of the genotypes.

According to Cargnelutti Filho et al. (2007), the existence of the genotypes $x$ environments interaction causes inconsistency in the indication of the best genotypes in the different environments. This fact evidences the need of deeper study about the adaptability and stability of the possible genotypes to be recommended (Melo et al., 2007). The interaction genotypes presence per environments is shown in Table 2. Experimental Station of UFLA 13/14 was 
Table 1. Summary of the individual analyzes of variance for upland rice lines in each environment considering the average of grain yield (GY).

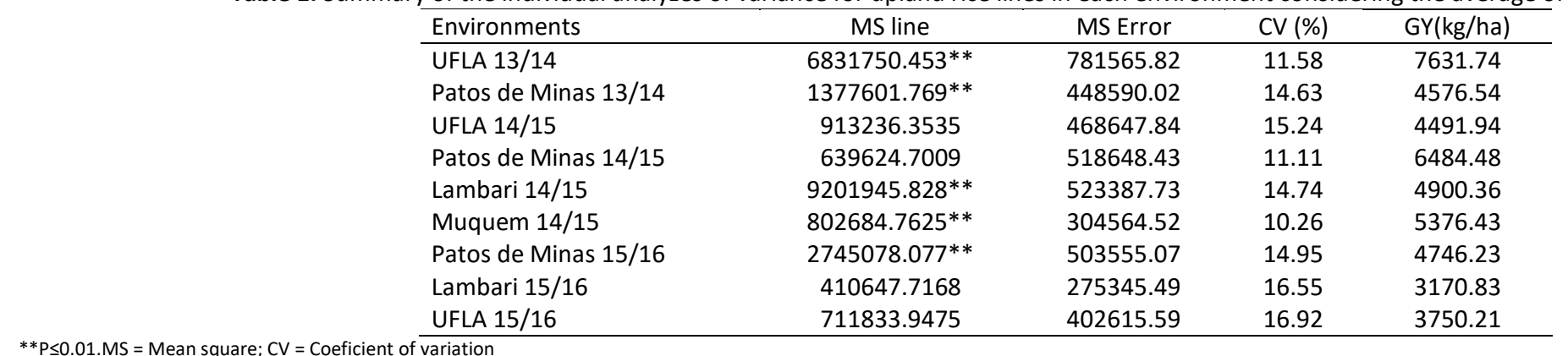

Table 2. Table of joint averages for the productivity $(\mathrm{kg} / \mathrm{ha}$ ) for the interaction Genotypes $x$ Environments for upland rice lines.

\begin{tabular}{|c|c|c|c|c|c|c|c|c|c|c|}
\hline \multirow[t]{2}{*}{ Lines } & \multicolumn{10}{|c|}{ Environments } \\
\hline & UFLA 13/14 & $\begin{array}{l}\text { Patos de Minas } \\
14 / 15\end{array}$ & $\begin{array}{l}\text { Muquem } \\
14 / 15\end{array}$ & $\begin{array}{l}\text { Lambari } \\
14 / 15\end{array}$ & $\begin{array}{l}\text { Patos de Minas } \\
15 / 16\end{array}$ & $\begin{array}{l}\text { Patos de Minas } \\
13 / 14\end{array}$ & UFLA 14/15 & UFLA 15/16 & Lambari 15/16 & Average \\
\hline CMG 2097 & $9194.3 \mathrm{aA} \ddagger$ & $6991.0 \mathrm{aB}$ & $6296.0 \mathrm{aB}$ & $6425.4 \mathrm{aB}$ & $3575.8 \mathrm{bC}$ & 3994.7 bC & $4465.0 \mathrm{aC}$ & $3694.4 \mathrm{aC}$ & $2759.7 \mathrm{aC}$ & 5266.26 \\
\hline CMG 1509 & 8873.0 aA & $6016.3 \mathrm{aB}$ & $5298.4 \mathrm{aB}$ & $6014.3 \mathrm{aB}$ & $4811.7 \mathrm{aB}$ & $4554.3 \mathrm{aB}$ & $5123.9 \mathrm{aB}$ & 3954. OaC & $3276.4 \mathrm{aC}$ & 5324.80 \\
\hline CMG 2085 & $8793.0 \mathrm{aA}$ & $6224.7 \mathrm{aB}$ & $5504.8 \mathrm{aC}$ & $5971.4 \mathrm{aB}$ & $5294.3 \mathrm{aC}$ & $5070.0 \mathrm{bD}$ & $4564.3 \mathrm{aC}$ & $3645.9 \mathrm{aD}$ & $3368.1 \mathrm{aD}$ & 5381.83 \\
\hline CMG 1511 & $8694.3 \mathrm{aA}$ & $6985.7 \mathrm{aB}$ & $5180.2 \mathrm{aC}$ & $6668.3 \mathrm{aB}$ & $5033.7 \mathrm{aC}$ & $4034.3 \mathrm{bD}$ & $4965.1 \mathrm{aC}$ & $3402.8 \mathrm{aD}$ & $3634.7 \mathrm{aD}$ & 5399.90 \\
\hline CMG 1987 & $8634.7 \mathrm{aA}$ & $6535.7 \mathrm{aB}$ & $4880.9 \mathrm{aC}$ & $6487.3 \mathrm{aB}$ & $2836.3 \mathrm{bD}$ & $3856.7 \mathrm{bC}$ & $4038.9 \mathrm{aC}$ & $3243.7 \mathrm{aC}$ & 3416.7aD & 4881.21 \\
\hline CMG 2089 & $8515.0 \mathrm{aA}$ & $7030.3 \mathrm{aB}$ & $5331.7 \mathrm{aC}$ & $5858.7 \mathrm{aC}$ & $4697.1 \mathrm{aC}$ & $4723.3 \mathrm{aC}$ & $4248.4 \mathrm{aD}$ & $3129.2 \mathrm{aD}$ & 3390.3aD & 5213.78 \\
\hline BRSMG Caçula & $7857.3 \mathrm{aA}$ & $6738.3 \mathrm{aA}$ & $5548.4 \mathrm{aB}$ & 1696.9 cD & $3627.9 \mathrm{bc}$ & $3453.7 \mathrm{bc}$ & $4282.5 \mathrm{aC}$ & $3334.7 \mathrm{aC}$ & $3016.7 \mathrm{aC}$ & 4395.16 \\
\hline CMG 1896 & $7813.3 \mathrm{aA}$ & $5819.3 \mathrm{aB}$ & $6154.8 \mathrm{aB}$ & $4830.2 \mathrm{aC}$ & $4929.7 \mathrm{aC}$ & $5512.0 \mathrm{aB}$ & $5413.5 \mathrm{aB}$ & $4619.4 \mathrm{aD}$ & $3829.2 \mathrm{aC}$ & 5435.71 \\
\hline CMG 2170 & $7805.7 \mathrm{aA}$ & $6286.0 \mathrm{aB}$ & $5496.0 \mathrm{aB}$ & $5963.5 \mathrm{aB}$ & $5950.6 \mathrm{aB}$ & $3965.0 \mathrm{bC}$ & $4540.5 \mathrm{aC}$ & $4612.5 \mathrm{aC}$ & 2429.2aD & 5227.67 \\
\hline CMG 1977 & $6869.3 \mathrm{bA}$ & $6238.7 \mathrm{aA}$ & $5490.5 \mathrm{aB}$ & $5307.9 \mathrm{aB}$ & $4474.6 \mathrm{aC}$ & $4446.0 \mathrm{bC}$ & $4869.0 \mathrm{aC}$ & $3712.5 \mathrm{aD}$ & $3012.5 \mathrm{aD}$ & 4935.67 \\
\hline BRSMG Relâmpago & $6682.3 \mathrm{bA}$ & $7160.3 \mathrm{Aa}$ & $4273.0 \mathrm{Ab}$ & $2814.3 \mathrm{BC}$ & $4794.3 \mathrm{Ab}$ & $5226.0 \mathrm{aB}$ & $4707.1 \mathrm{aB}$ & $3543.0 \mathrm{aC}$ & $3062.5 a C$ & 4695.87 \\
\hline BRS Esmeralada & $5357.3 \mathrm{bA}$ & 5855.7 aA & $5471.4 \mathrm{aA}$ & $3565.1 \mathrm{bB}$ & $5401.9 \mathrm{Aa}$ & $5291.0 \mathrm{aA}$ & $3734.9 \mathrm{aB}$ & $4281.9 \mathrm{aB}$ & $3065.3 a B$ & 4669.39 \\
\hline BRSMG Caravera & $4123.0 \mathrm{bC}$ & 6416.3 aA & $4967.5 \mathrm{aB}$ & $2101.6 c D$ & $6273.3 \mathrm{aA}$ & $5373.3 \mathrm{aB}$ & $3442.1 \mathrm{aC}$ & $3577.8 \mathrm{aC}$ & 2959.7aD & 4359.40 \\
\hline Average & 7631.73 & 6484.48 & 5376.43 & 4900.38 & 4746.25 & 4576.95 & 4491.94 & 3750.21 & 3170.85 & 5014.36 \\
\hline
\end{tabular}

₹ Means followed by the same lowercase letter within columns or the same uppercase letter within lines are not significantly different based on $\mathrm{P} \leq 0.01$. 
Table 3. Stability analysis of the average grain productivity (GP) for upland rice lines according to Wricke model (1965).

\begin{tabular}{lccc}
\hline Lines & $\mathrm{GP}(\mathrm{kg} / \mathrm{ha})$ & $\mathrm{W}_{\mathrm{i}}$ & $\mathrm{W}_{\mathrm{i}}(\%)$ \\
\hline BRS Esmeralda & 4646.35 & 2787.42 & 7.72 \\
CMG 2170 & 5261.67 & 2776.84 & 7.69 \\
BRSMG Caçula & 4532.57 & 2778.78 & 7.70 \\
CMG 2085 & 5178.82 & 2761.98 & 7.65 \\
BRSMG Caravera & 4087.65 & 2817.37 & 7.80 \\
BRSMG Relâmpago & 4558.32 & 2768.20 & 7.67 \\
CMG 1511 & 5044.04 & 2778.87 & 7.70 \\
CMG 2089 & 5513.44 & 2779.42 & 7.70 \\
CMG 1896 & 5598.71 & 2770.49 & 7.67 \\
CMG 2097 & 5482.67 & 2766.81 & 7.66 \\
CMG 1977 & 4833.67 & 2768.57 & 7.67 \\
CMG 1509 & 4731.72 & 2767.15 & 7.66 \\
CMG 1987 & 4808.46 & 2761.44 & 7.65 \\
\hline
\end{tabular}

$\mathrm{W}_{\mathrm{i}}=$ ecovalence $\mathrm{W}_{\mathrm{i}}(\%)$ = ecovalence in percentage.

Table 4. Stability analysis of the average grain productivity (GP) for upland rice lines according to Annicchiarico model (1992).

\begin{tabular}{llll}
\hline Lines & GP $(\mathrm{kg} / \mathrm{ha})$ & $\mathrm{SD}(\%)$ & $\mathrm{I}_{\mathrm{i}}$ \\
\hline BRS Esmeralda & 4646.35 & 22.57 & 98.2 \\
CMG 2170 & 5261.67 & 23.35 & 105.7 \\
BRSMG Caçula & 4532.57 & 20.95 & 90.3 \\
CMG 2085 & 5178.82 & 11.22 & 104.4 \\
BRSMG Caravera & 4087.65 & 31.19 & 86.3 \\
BRSMG Relâmpago & 4558.32 & 15.89 & 92.3 \\
CMG 1511 & 5044.04 & 22.48 & 101.2 \\
CMG 2089 & 5513.44 & 19.45 & 108.8 \\
CMG 1896 & 5598.71 & 16.49 & 108.8 \\
CMG 2097 & 5482.67 & 16.9 & 109.1 \\
CMG 1977 & 4833.67 & 12.74 & 99.1 \\
CMG 1509 & 4731.72 & 13.89 & 94.0 \\
CMG 1987 & 4808.46 & 13.32 & 95.7 \\
\hline
\end{tabular}

SD = Standard deviation $\mathrm{l}_{\mathrm{i}}=$ confidence index .

Table 5. Stability analysis of the average grain productivity (GP) for upland rice lineas according to Lin and Binns model (P) (1988).

\begin{tabular}{lll}
\hline Lines & $\mathrm{GP}(\mathrm{kg} / \mathrm{ha})$ & $\mathrm{P}_{\mathrm{i}}$ \\
\hline BRS Esmeralda & 4646.35 & 7,856 \\
CMG 2170 & 5261.67 & 3,408 \\
BRSMG Caçula & 4532.57 & 8,028 \\
CMG 2085 & 5178.82 & 2,748 \\
BRSMG Caravera & 4087.65 & 14,117 \\
BRSMG Relâmpago & 4558.32 & 7,346 \\
CMG 1511 & 5044.04 & 4,298 \\
CMG 2089 & 5513.44 & 2,410 \\
CMG 1896 & 5598.71 & 2,077 \\
CMG 2097 & 5482.67 & 2,020 \\
CMG 1977 & 4833.67 & 5,468 \\
CMG 1509 & 4731.72 & 4,772 \\
CMG 1987 & 4808.46 & 4,623 \\
\hline $\mathrm{P}_{\mathrm{i}}=$ stability and adaptability estimator. & &
\end{tabular}

Table 6. Geographic coordinates of the places where the experiments with upland rice lines were installed.

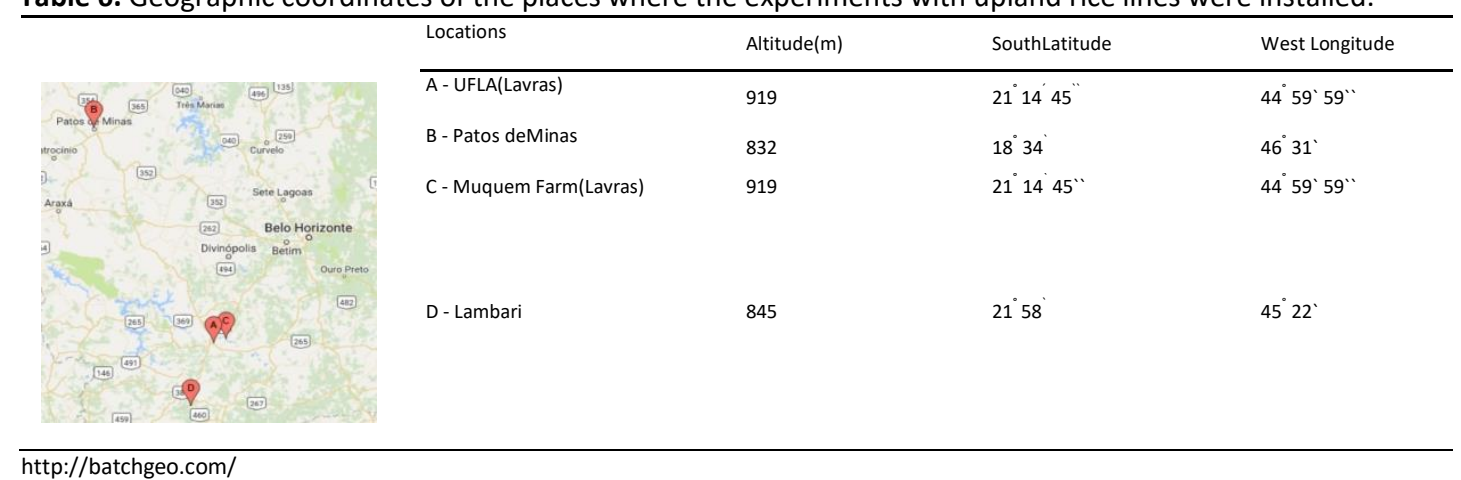


Table 7. Origin of the upland rice lines used in the experiments.

\begin{tabular}{lc}
\hline Lines & Origin \\
\hline BRS Esmeralda & Embrapa \\
CMG 2170 & UFLA/Epamig/Embrapa \\
BRSMG Caçula & UFLA/Epamig/Embrapa \\
CMG 2085 & UFLA/Epamig/Embrapa \\
BRSMG Caravera & UFLA/Epamig/Embrapa \\
BRSMG Relâmpago & UFLA/Epamig/Embrapa \\
CMG 1511 & UFLA/Epamig/Embrapa \\
CMG 2089 & UFLA/Epamig/Embrapa \\
CMG 1896 & UFLA/Epamig/Embrapa \\
CMG 2097 & UFLA/Epamig/Embrapa \\
CMG 1977 & UFLA/Epamig/Embrapa \\
CMG 1509 & UFLA/Epamig/Embrapa \\
CMG 1987 & UFLA/Epamig/Embrapa \\
\hline
\end{tabular}

the best environment, totally differing from the other environments, and showed higher average of grain productivity. Patos de Minas 14/15 environment occupied the second position, with prominence of lines CMG 2089 and, BRSMG Relâmpago. It is also worth mentioning that cultivar BRSMG Caçula expressed lower yields among all in the Lambari 14/15 environment, an expected fact because this line is classified as a premature material, according to Soares et al. (2013).

It is also important to highlight that in the environments Patos de Minas 13/14, 15/16, Lambari 15/16 and UFLA $13 / 14$, there was a difference of productive behavior among the lines. While in the other environments, the lines had similar behavior regarding grain productivity (Table 2 ).

Considerations regarding this interaction are essential for the efficiency of plant breeding, since the main objective of breeding is to select adapted and productive plants to a greater number of possible environments. The effect of the genotypes $x$ environments interaction can endanger the selection, where the stratification of the environments and the selection directed to specific regions is necessary. However, these strategies are not sufficient to control factors related to the growing season, such as temperature and precipitation (Cruz et al., 2004).

\section{Phenotypic plasticity - Wricke, Annichiaricco and Lin and Binns methods}

To be more successful in the selection and recommendation of cultivars, besides the evaluation of the lines in the highest number of possible environments, it is necessary to select the lines through adaptability and stability estimates. There are several methods capable of obtaining estimates about the phenotypic plasticity of lines, among which we can mention the most commonly employed, such as Wricke (1965), Annichiaricco (1992) and Lin and Binns (1988).

The Wricke method (1965) estimates the contribution of each line to the interaction, where those with the highest estimation of $\mathrm{Wi}$ - ecovalence (\%) are classified as the most adapted. Wi data obtained by each line in the average of the environments is shown in Table 3 . It is worth noting that the contribution of the interaction among the lines did not show any difference, which means that there is a similarity in the adaptability estimates of these lines.

Papers published by Polizel et al. (2013) on soybean, obtained results to ecovalence estimates (Wricke, 1965). In that study, some lines were more stable and with medium adaptability. Franceschi et al. (2010), studying methods for adaptability and stability in wheat lines, found by Wricke methodology that wheat cultivars had the lowest values of Wi, and were considered the most stable. However, among these, only those with productivity above $4,000 \mathrm{~kg} / \mathrm{ha}$ were classified as being of superior grain yield. Not all cultivars with higher stability (lower Wi) are those that obtained high grain yield.

Averages estimates of lines and parameters of adaptability and stability from cultivars and lines obtained by Annicchiarico (1992) methods can be appreciated in Table 4. In the method proposed by Annicchiarico, stability is measured by the superiority of the line in relation to the average of each environment. The method is based on the confidence index estimation of a certain genotype showing relatively superior behavior (Barros et al., 2012). Thus, based on the confidence index or recommendation index, the following lines may be indicated: CMG 2097, which showed the highest adaptability from all lines, followed by CMG 2089, CMG 1896, CMG 2170, and CMG 2085 as the lines that stood out in relation to the grain average productivity.

Thus, assuming the variance homogeneity among the environments, the regression of the percentage values of each environment, according to the environmental indexes, will also present regression coefficient of the environmental indexes close to the unit. In this way, if the cultivar has the average percentage value as $110 \%$ of the environment average constant throughout the environments, its standard deviation will be zero and it will be equal to $110 \%$ (also, I will be equal to $110 \%$ ); therefore, this cultivar will present broad adaptability (Schmildt and Cruz, 2005). By the results obtained by the same method, the highlighted lines above also present a broad adaptability by the efficiency of this method.

In regards to the adaptability and stability analysis proposed by Lin and Binns (1988), which estimates Pi (deviation around maximum), the genotypes with the lowest $\mathrm{Pi}$ values are classified as higher phenotypic plasticity. The $\mathrm{Pi}$ values for each evaluated line are presented in Table 5. Lines CMG 2097, CMG 1896, CMG 2089, CMG 2085, and CMG 2170 obtained lower estimates of $\mathrm{Pi}$, where they were considered as more adapted and stable according to the arguments of the method. And the less adapted and stable genotype, that is, with higher Pi value and lower average of grain productivity, was BRSMG Caravera, followed by BRSMG Caçula, BRS Esmeralda and BRSMG Relâmpago.

It is worth noting that high estimates of $\mathrm{Pi}$ are always associated with values of grain productivities lower than the desired one, which allows, through the use of the Lin and 
Binns (1988) methodology in plant breeding, the selection of simultaneously adapted and stable genotypes.

In the present study, the non-parametric method of Lin and Binns (1988), modified by Carneiro (1998), presented satisfactory results and with easier interpretation, besides better discriminating the lines about the performance in both favorable and unfavorable environments. These results corroborate with Atroch and Nunes's results (Atroch and Nunes, 2000) that indicated Lin and Binns' method for future use in rice breeding programs.

\section{Materials and Methods}

\section{Experiment procedure}

The experiments were conducted in nine environments, corresponding to the combination of locations and agricultural years. In the harvests of 2013/2014, 2014/2015, and 2015/2016, experiments were conducted at experimental stations at UFLA in Lavras-MG and in Patos de Minas-MG; at UFLA, Muquem Experimental Farm (Muquem) in Lavras-MG, Lambari, and Patos de Minas; and at UFLA, Lambari and Patos de Minas, respectively. The locations present semi-humid tropical climate and tropical altitude climate and low natural fertility soil, ferralsol (latosols) (FAO, 1988), and show ideal edaphoclimatic conditions for this study type (Table 6).

The Cultivation Value and Use (CVU) experiment was used, which is a large plot, with a lower line number, only considering the highland rice elite lines of the breeding program of the partnership between UFLA, EPAMIG and Embrapa Rice and Beans. The lines in this experiment are cultivated in different locations, under different agricultural years, for later selection and launching. Thus, a total of thirteen elite lines from the upland rice breeding program were used (Table 7).

\section{Experimental design}

The experiments were conducted in randomized block design with 3 replications. The plots consisted of five rows of 4 meters with seeding density of 80 seeds/meter. The cultivation treatments used in the experiments were the same as those recommended for rice cultivation in the evaluation regions, however, without fungicides application, since the evaluation of the diseases incidence was part of the methodology. During the experiments procedure, the grain yield was evaluated by manual harvesting of each plot as it reached the maturation point

\section{Statistical analysis}

Individual and joint analyzes of variance were performed with the statistical program SAS (2000). The Scott-Knott test (Scott-Knott, 1974) was used for averages grouping ( $P \leq$ 0.01 ). For stability and adaptability analysis, the stability software was used through three methods: Wricke (1965), Annichiaricco (1992) and Lin and Binns (1988), according to the descriptions below:

- Wricke Method (1965): with the estimates of grain yield averages of the plots per environment, the stability of the lines was estimated by the Wricke method (1965). The ecovalence $\left(W_{i}\right)$ was estimated through the partition of the sum of the squares of genotypes per environment interaction (ge), according to the estimator: $\mathrm{W}_{\mathrm{i}}=\Sigma(\mathrm{ge})_{\mathrm{ij}}{ }^{2}$ with $(\mathrm{ge})_{\mathrm{ij}}=\bar{y}_{\mathrm{ij}}-\bar{y}_{\mathrm{i}}-\bar{y}_{\mathrm{j}}-\overline{\mathrm{y}}$, in which: $\bar{y}_{\mathrm{ij}}$ is the adjusted average of cultivar $i$ in the environment $j ; \bar{y}_{i}$ is the adjusted average of the line $i$ in the evaluated environments; $\bar{y}_{j}$ is the adjusted average of the environment $\mathrm{l} ; \overline{\mathrm{y}}$ is the general average. The significance of the stability of the lines was verified by the statistical test presented in Resende (2002).

- Annicchiarico Method (1992): in order to study the adaptability of the evaluated lines, the Annicchiarico method (1992) was used, which estimates the confidence index in the adoption of a certain line. The genotype performance evaluation methods shows, through the regression use, that the environmental index is the dependent variable itself (average of the cultivars at each location) subtracted from a constant, which in this case is the general average. Thus, the homogeneity of phenotypic variance among the environments is allowed. The procedures for the calculation by the method proposed by Annicchiarico (1992) are initially given with the transformation of the averages of each cultivar in each environment to the percentage of the average of the environment, where the standard deviation and the average of the percentages of each cultivar are estimated in a later moment. With these estimates, the confidence index $\left(\mathrm{I}_{\mathrm{i}}\right)$ is obtained by means of the following estimator: $I_{i}=\bar{y}-z_{(1-}$ ${ }_{\alpha)} \sigma_{i}$, where: $I_{i}$ is the confidence index; $\bar{y}$ is the average; $z_{(1-}$ ${ }_{\alpha)}$ is the value in the standardized normal distribution in which the function accumulated distribution reaches the value $(1-\alpha)$, with a level of significance pre-fixed by the author in $0.25 ; \sigma_{i}$ is the standard deviation.

- Lin and Binns Method: is defined as the average square of the distance between the cultivar average and the maximum average response for all environments. This measure is estimated by: $\mathrm{Pi}=\Sigma\left(\mathrm{X}_{\mathrm{ij}}-\mathrm{M}_{\mathrm{j}}\right)^{2} / 2 \mathrm{n}$, where: $\mathrm{Pi}=$ estimate of stability and adaptability of cultivar $\mathrm{i} ; \mathrm{X}_{\mathrm{ij}}=$ productivity of $i$-th cultivar in the $j$-th environment; $M_{j}=$ maximum response observed among all the lines in $j$ environment; $\mathrm{n}=$ number of environments.

\section{Conclusion}

Our results showed that all experiments had average productivities from $3,170.83 \mathrm{~kg} / \mathrm{ha}$ for Lambari's environment in the $15 / 16$ harvest to $7,631.74 \mathrm{~kg} / \mathrm{ha}$, that is, above average in Minas Gerais state ( $2.3 \mathrm{t} / \mathrm{ha}$ ). Besides, we found interaction of genotypes per environments, emphasizing the need of recommendation of lines with high phenotypic plasticity. It is worth noting that the contribution of the interaction among lines did not show any difference, which means that there is a similarity in adaptability estimates of lines evaluated according to the Wricke method. By the Annicchiarico and Lin and Binns methods, lines CMG 2097, CMG 1896, and CMG 2089 were identified with good phenotypic plasticity, where these lines are promising for recommendation in Minas Gerais state, as well as in similar environments under low fertility natural soil, ferralsol (latosols), with tropical semi-humid climate and tropical altitude climate. 


\section{Acknowledgments}

To the National Council for Scientific and Technological Development $(\mathrm{CNPq})$, and the Foundation for Research in Minas Gerais State (FAPEMIG) for financing. To the Federal University of Lavras (UFLA) for scholarship. To the Brazilian Company of Agricultural Research (Embrapa), Agricultural Research Company of Minas Gerais (EPAMIG) and Federal University of Lavras (UFLA) for upland rice lines.

\section{References}

Annicchiarico P (1992) Cultivar adaptation and recommendation from alfalfa trials in Northern Italy. J Genet Breed. 46:269-278.

Atroch AL, Nunes GHS (2000) Progresso genético em arroz de várzea úmida no Estado do Amapá. Pesq Agropec Bras. 35:767-771.

Balestre M, Santos VB, Soares AA, Reis MS (2010) Stability and adaptability of upland rice genotypes. Crop Breed Appl Biotechnol. 10:357-363.

Barros HB, Sediyama T, Melo AV, Fidelis RR, Capone A (2012) Adaptabilidade e estabilidade de genótipos de soja por meio de métodos uni e multivariado. J Biotec Biodivers. 3:49-58.

Borges V, Soares AA, Reis MS, Resende MDV, Cornélio VMO, Leite NA, Vieira AR (2010) Desempenho genotípico de linhagens de arroz de terras altas utilizando metodologia de modelos mistos. Bragantia. 69:833-841.

Camargo Rocha NP, Moda-Cirino V, Destro D, Fonseca Júnior NS, Prete CEC (2010) Adaptabilidade e estabilidade da característica produtividade de grãos dos grupos comerciais carioca e preto de feijão. Cienc Agr. 31:39-54.

Cargnelutti Filho A, Perecin D, Malheiros EB, Guadagnin JP (2007) Comparação de métodos de adaptabilidade e estabilidade relacionados à produtividade de grãos de cultivares de milho. Bragantia. 66:571-578.

Cargnin A, Souza MA, Pimentel AJB, Fogaça CM (2008). Interação genótipos e ambientes e implicações na adaptabilidade e estabilidade de arroz sequeiro. $\mathrm{R}$ Bras Agrociência. 14:49-57.

Carneiro PCS (1998) Novas metodologias de análise da adaptabilidade e estabilidade de comportamento. Theses Federal University of Viçosa, Viçosa.

CONAB (2016) Informe agropecuário 2016. Avaliable at: http://www.conab.gov.br. Access: November 14th, 2016.

Cruz CD, Regazzi AJ, Carneiro PCS (2004) Modelos biométricos aplicados ao melhoramento genético, 3 ed. Federal University of Viçosa, Viçosa.

FAO (1988) FAO/Unesco Soil Map of the World. Avaliable at: http://library.wur.nl/isric/fulltext/isricu i9264 001.pdf. Access: September 15th, 2017.

Ferreira CN, Villar PM (2003) Sistemas de produção $n 1$. Emprapa Arroz e Feijão, Santo Antônio de Goiás.

Franceschi L, Benin G, Marchioro VS, Martin TN, Silva RR, Silva CL (2010) Métodos para análise de adaptabilidade e estabilidade em cultivares de trigo no Estado do Paraná. Bragantia. 69:797-805.

Lin CS, Binns MR (1988) A superiority measure of cultivar performance for cultivar $x$ location data. Can. J. Plant Science. 68:193-198.
Melo LC, Melo PGS, Faria LC, Diaz JLC, Del Peloso MJ, Rava CA, Costa JGC (2007) Interação com ambientes e estabilidade de genótipos de feijoeiro-comum na Região Centro-Sul do Brasil. Pesq Agropec Bras. 42:715-723.

Molina LMR (2007) Avaliação de interação genotipoxamabiente em linhagen de arroz (Oriza sativa L.). Dissertation - Faculty of Agrarian and Veterinary Sciences,

Paulista State University, Jaboticabal.

Morais LK, Silva RM, Chiorato AF, Azzini LE, Villela OV, Gallo PB (2008) Adaptabilidade e estabilidade fenotípica de genótipos de arroz irrigado para o Estado de São Paulo. Rev Biociências. 14:9-16.

Nascimento WF (2008) Caracterizaçao morfológica de acessos de arroz de terras altas. Dissertation - Rural Federal University of Pernambuco, Recife.

Pimentel-Gomes F (2000) Curso de estatística experimental. 14th ed. Luiz de Queiroz College of Agriculture, Piracicaba.

Polizel AC, Juliatti FC, Hamawaki OT, Hamawaki RL, Guimarães SL (2013) Adaptabilidade e estabilidade fenotípica de genótipos de soja no Estado do Mato Grosso. Biosci J. 29:910-920.

Regitano Neto A, Ramos Junior EU, Gallo PB, Freitas JG, Azzini LE (2013) Behavior of upland rice genotypes in the state of São Paulo, Brazil. Rev Cienc Agron. 44:512-519.

Resende MDV (2002) Genética biométrica e estatística no melhoramento de plantas perenes. Embrapa Florestas, Brasília.

Santos VB (2009) Avaliação de linhagens genotípicas do arroz em terras altas via modelos mistos. Theses - Federal University of Lavras, Lavras.

SAS Institute (2000) SAS/STAT User's Guide, Version 8. SAS Inst., Cary, NC.

Schmildt ER, Cruz CD (2005) Análise da adaptabilidade e estabilidade do milho pelos métodos de Ebehert e Russel e de Annicchiarico. Ceres. 52:45-58.

Scott A, Knott M (1974) A cluster-analysis method for grouping means in analysis of variance. Biometrics. 30:507-512.

Soares AA, Reis MS, Cornélio VMO, Leite NA, Soares PC, Santos VB (2013) BRSMG Caçula: very early upland rice cultivar for Minas Gerais. Crop Breed Appl Biotechnol. 13:208-211.

Terra TGR, Leal TCAB, Borém A, Rangel PHN (2013) Tolerância de linhagens de arroz em terras altas à seca. Pesq Agropec Trop. 43:201-208.

Walter LC, Streck NA, Rosa HT, Ferraz SET, Cera JC (2010) Mudanças climáticas e seus efeitos na cultura do arroz. Cienc Rural. 40:2411-2418.

Wricke G (1965) Zur Berechnung der okovalenz bei sommerweizen und hafer. Z. Pflanzenzuchtung. 52:127138. 